\title{
Polymeric Substances in Agriculture
}

Advance Research in

Waleed Fouad Abobatta*

Horticulture Research Institute, Agriculture Research Centre, Egypt

Organic and Inorganic

Abstract

\section{Chemistry (AROIC)}

Volume 3 Issue 1, 2022

Article Information

Received date : February 11, 2022

Published date: February 28, 2022

*Corresponding author

Waleed Fouad Abobatta, Horticulture

Research Institute, Agriculture Research

Centre, Egypt

\section{Keywords}

Polymeric Substances; Agricultural

Sector; Plant Growth; Productivity;

Environment

DOI:10.54026/AROIC/1007

Distributed under Creative Commons CC-BY 4.0
The agricultural sector is subjected to different challenges particularly abiotic stress due to severe climate conditions. Water shortage is considered the main restricting factor for agricultural production. Polymeric substances could play a key role in improving various plant productivity and providing numerous advantages under light texture soils and dryness conditions. It is maintaining the continuous supply of water and nutrients for the plants, enhancing soil

\section{Introduction}

Due to the rapidly increasing world population, which is expected reach to 9 billion by 2050 and 100 billion in 2100 [1], there is more attention to various materials that could assist in increasing food production and sustaining water resources [2]. The agricultural sector is one of the most important sectors worldwide, due to the increasing demand for food products to provide sufficient food for humanity, besides that, the agricultural sector is the most water consuming. In addition, abiotic stresses like water shortage, high temperature, and higher solar radiation, increase negative impacts on plant growth and productivity [3]. Furthermore, insufficient rhizosphere humidity is considered the limiting factor for crop production, particularly under sandy soil or light-textured soils conditions. Therefore, the use of modern technologies in this field helps to sustain natural resources and provide adequate food and production requirements. Polymers are one of the promising materials that could retain water and nutrients for long times and provide to plants when the soil starts drying [4]. Polymeric substances are considered an important point in the agricultural sector in the current era particularly under water scarcity in aridity conditions, which affect nutrient availability for plants [5]. In addition, polymers have a high swelling capacity and retain the ability of water that maintains the humidity levels around the root system, consequently, reducing water consumption, increasing irrigation intervals, and reducing spreading root diseases, particularly fungal diseases [6] Furthermore, polymers have the ability to regulate nutrient releasing, which, reserves the nutritional supply for a longer period, consequently, reducing crop production costs and sustaining the environment. There are different benefits for using polymers in the agricultural sector like enhancing aeration of heavy-clay soil, mitigating the negative impact of drought stress on plant growth, increasing crop productivity, and sustained release of water and nutrients [5]. This article explores the most important benefits and applications of polymers in the agricultural sector.

Polymer classification

Polymeric materials could be classified into two main groups [7], according to the original materials as follow:

a) Natural - consist of polysaccharide-based (e.g. chitosan, starch, and cellulose).

b) Artificial - synthesis from petrochemical-based like polyethylene glycol, polyacrylic acid, and methacrylic acid).

While, there are different classifications of agricultural polymers,

a) Based on the polymeric composition (Homopolymeric-Copolymeric-Multipolymer).

b) Based on the original materials (Natural and Artificial).

c) Based on the physical structure and chemical composition (Amorphous, Semi-crystalline, and Crystalline).

d) Based on the type of cross-linking (chemically cross-linked and physically cross-linked)

Mode of action

After irrigation or rainfall, polymeric materials swell by absorbing water and nutrients, and retaining humidity around the rhizosphere for longer times [8], when soil becomes dry, polymers release water and nutrients slowly for plant, which increase the plant tolerance for dry conditions [9]. Agricultural polymeric materials could absorb and retain a large amount of water reach to hundred folds of water (weight by weight), each one gram of polymer could retain 400 grams of water and release $90 \%$ of absorbed water [6]. Furthermore, the super absorbent polymer could absorb 900 fold of water (Liu et al, 2006). Therefore, polymeric materials could be one of effective means to improve water use efficiency in the agricultural sector and increase crop productivity under water shortage conditions [5].

Benefits of polymers in the agricultural sector

The agriculture sector is subjected to different challenges, while water scarcity is considered a limiting factor for crop production, particularly under aridity conditions. Therefore, there is more attention to using polymeric materials in the agricultural sector, to sustain agricultural production worldwide [10].

The main benefits of the polymer include:

a) Improving water retention

b) Adequate supply of water for plants and increase watering intervals.

c) Increase nutrient availability for a long time.

d) Enhancing plant growth

e) Protect the environment by reducing the leaching of conventional fertilizers. 


\section{Applications in the agricultural sector}

The agriculture sector is subjected to different challenges, while water scarcity is considered a limiting factor for crop production, particularly under aridity conditions [8]. Therefore, there is more attention to using polymeric materials in the agricultural sector, to sustain agricultural production worldwide [11]. include:

There are different applications of polymeric substances in agricultural sector that

a. Biosensors.

b. Water-saving substances.

c. Soil conditioners.

d. Food packaging (Edible polymer-based hydrogels).

e. Nutrient carrier.

f. Controlled release agrochemicals.

Impact of polymer on soil characters

Polymers substances enhancing soil characters by different modus:

i. Enhancing soil aeration.

ii. Improving water-holding capacity.

iii. Rising the field capacity of sandy soil for a longer period.

iv. Increasing the penetrability of heavy soils.

v. Protect soil by minimizing erosion average.

Some field uses of polymeric substances

a. Enhance the productivity of Navel orange under sandy soil conditions [12]

b. Increasing survival rate of seedlings [10].

c. Improving date palm growth and productivity under water shortage conditions [13].

\section{Conclusion}

Under challenges of water shortage facing the agricultural sector, polymeric substances could play a key role in improving crop productivity and sustaining natural resources, using polymers in agriculture particularly providing different benefits under aridity conditions and in light texture soils. It is maintaining the slow release of water and nutrients for the plants, improves soil character, protects the environment from pollution by reducing the leaching of agrochemicals.

\section{References}

1. Singh R, Srivastava P, Singh P, Upadhyay S, Raghubanshi AS (2019) Human overpopulation and food security: challenges for the agriculture sustainability. In Urban agriculture and food systems: breakthroughs in research and practice, IGI Global, US, pp. 439-467.

2. Hussain MI, Muscolo A, Farooq M, Ahmad W (2019) Sustainable use and management of non-conventional water resources for rehabilitation of marginal lands in arid and semiarid environments. Agricultural water management 221: 462-476?

3. Abobatta WF (2020) Plant Responses and Tolerance to Combined Salt and Drought Stress. In Salt and Drought Stress Tolerance in Plants, Springer pp. 17-52.

4. Rabat NE, Hashim S, Majid RA (2016) Effect of different monomers on water retention properties of slow release fertilizer hydrogel. Procedia engineering, 148: 201-207.

5. Abobatta WF (2019) Hydrogel Polymer: A New Tool for Improving Agricultural Production. Academ J Polym Sci 3(2): 555609

6. Ai F, Yin X, Hu R, Ma H, Liu W (2021) Research into the super-absorbent polymers on agricultural water. Agricultural Water Management 245: 106513.]

7. Liu M, Liang R, Zhan F, Liu Z, Niu A (2006) Synthesis of a slow-release and superabsorbent nitrogen fertilizer and its properties. Polymers for advanced technologies 17(6): 430-438.

8. Kumar R, Yadav S, Singh V, Kumar M, Kumar M (2020) Hydrogel and its effect on soil moisture status and plant growth: A review. Journal of Pharmacognosy and Phytochemistry 9(3): 1746-1753.

9. Zekry M, Nassar I, Salim H, Abdallah A (2020) The Potential of super absorbent polymers from diaper wastes to enhance water retention properties of the soil. Soil \& Environment 39(1).

10. Yang L, Yang Y, Chen Z, Guo C, Li S (2014) Influence of super absorbent polymer on soil water retention, seed germination and plant survivals for rocky slopes eco-engineering. Ecological Engineering 62: 27-32.7

11. Behera S, Mahanwar PA (2019) Superabsorbent polymers in agriculture and other applications: a review, Polymer-Plastics Technology and Materials, 59(4): 341-356.

12. Abobatta WF, Khalifa SM (2019) Influence of Hydrogel Composites Soil Conditioner on Navel Orange Growth and Productivity. J Agri Horti Res 2(2): $1-6$.

13. Gribaa A, Dardelle F, Lehner A, Rihouey C, Burel C, et al. (2012) Effect of water deficit on the cell wall of the date palm (Phoenix dactylifera 'Deglet nour', Arecales) fruit during development. Plant Cell Environ 36(5): 1056-1070. 